\title{
Raising a Market Show Hog
}

One of the most rewarding and educational $4-\mathrm{H}$ projects is raising, finishing, and showing a market hog. Many younger 4-H'ers excitedly wait for the day when they can choose their first show pig. Parents and youth need to understand that while the hog project is an excellent opportunity, it requires a great deal of thought, preparation, time, and resources. The purpose of this publication is to help parents and youth understand some of the commitments and preparations involved in raising a hog, as well as what to expect and what to do in order to successfully complete the project.

Pork is the most-eaten meat in the world. The United States is second only to China in pork production. Each year the average American eats over 60 pounds of pork (Pork Checkoff, 2019). Pork was a favorite meat for early Americans. The Spanish brought hogs with them to Florida during their explorations, and some of these hogs escaped. Many of these escaped hogs, combined with hogs raised on open range in Florida through 1948, have thousands of wild descendants still roaming Florida's woods.

Domesticated hogs grow faster and produce more meat than their feral relatives. Breeds like the Hampshire, Duroc, Yorkshire, Poland China, Spot, Landrace, and others have been genetically selected to efficiently convert feed into high-quality carcasses. Today's domestic pigs reach ideal slaughter weight, around 280 pounds, at about six months of age.

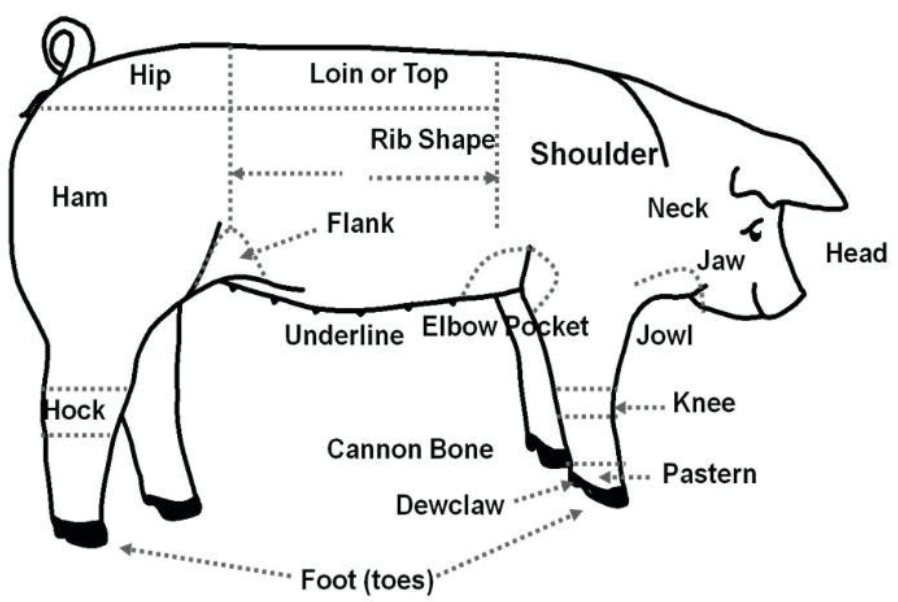

Figure 1. Parts of a pig. Learning the parts of a pig will help in choosing an animal (Myers et al., 2012). Credits: UF Animal Sciences

\section{Deciding to do a Hog Project/ General Requirements}

The goal of the market hog project is for a young person to purchase a quality pig and raise this animal with the goal that it should produce a high-quality, relatively lean and muscular US Number 1 carcass at about 280 pounds with a backfat thickness between 0.5 and 1 inch (see Figure 2). The young person, with parental oversight, is responsible for feeding the animal, making sure the animal's medical needs are met, providing proper housing/shelter for the animal, keeping this area clean, gentling the animal, and training the animal to show. This is a lot of work, and younger 4-Hers in particular need to consider the time and hard work involved with a successful project. At the same time, it can also be one of the most rewarding activities a 4-H member can do. If a young person is busy with other extracurricular activities and won't have time every day to devote to this project, that 4-H member might need to choose a different project. 
There is also a financial consideration for participation. Some 4-Hers spend several hundred dollars purchasing a show pig, feed, and materials to house a pig. While most 4-Hers sell their hog at the youth fair at the completion of the project, a profit is not guaranteed.

Another consideration is an actual location in which to do the project. Not everyone is zoned to have hogs on their property. Those youth interested in a 4-H market hog project need to confirm with their local zoning board that they are allowed to raise a pig before beginning the project. Sometimes a special $4-\mathrm{H}$ variance can be granted to 4-H club members; check with your local zoning board.

\section{Typical Market Hogs Today}

Today's typical market pig finishes at an average of 282 pounds live weight. This animal will have an average backfat thickness over the $10^{\text {th }}$ rib of 0.68 inches. This animal will produce a pork carcass that weighs 211 pounds on average, with a loin-eye area of 7.93 inches, and it will produce a carcass that on average is 55.15 percent lean meat, which means today's typical market hog will produce 116.40 pounds of lean meat on average (Pork Checkoff, 2019).

The youth swine exhibitor should, within the parameters of the show rules, strive to produce a similar animal that would grade out as a US Number 1 market hog according to USDA standards. Because these are show animals, the goal should be the high end of the US Number 1 category, which means a large-framed, heavy-muscled animal with an adequate degree of fatness. Figure 2 includes pictures and a description of USDA grades for feeder pigs (USDA, 1988 ; 2019).

\section{Feeder Pigs \\ Official U.S. Grades}
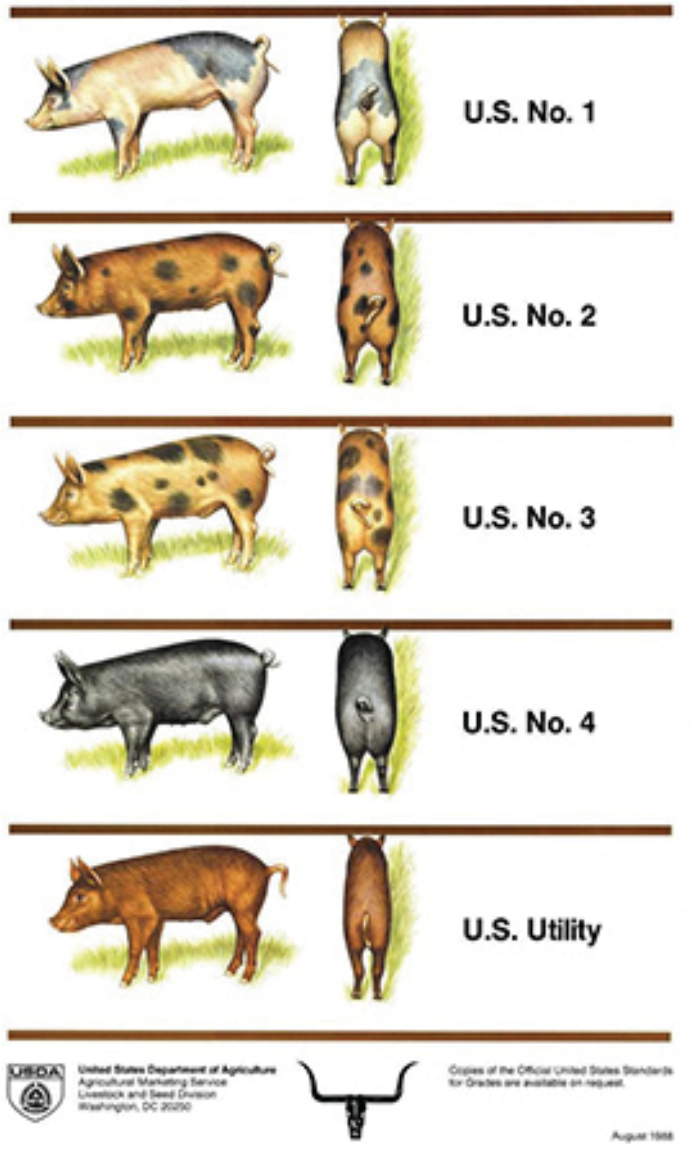

U.S. No. 1

U.S. No. 1 grade feeder pigs are very thick-muscled and have a large frame that should allow the animal to produce a U.S. No 1 carcass at ideal market weight, about 280 pounds. This carcass will have a high amount of muscle with only the correct amount of fatmess. From the rear it is apparent that the legs are set wide apart because of the very thick muscling; the hams and ahoulders are wider than the loins; and the back is well-rounded. The animal is trim throughout and ghould maintain a high degree of trimness even at market weight.

U.S. No. 2

U.S No. 2 grade feeder pigs have moderately thick muscling in the hams and shoulders and a moderately large frame. This znimal should reach $280 \mathrm{lk}$, with only a moderate degree of fatness. Viewed from the rear, the hams are slightly wider than the loin, and the back is slightly full and well-rounded. The legs are moderately wide-set, indicating moderately thick muscling. From the side it has begun to lose the look of trimness shown by the No. 1 animal, in that the jowl and flank are beginning to fill with fat. Feeder pigs in this grade are expected to produce U.S. No. 2 grade carcasses when slaughtered at around 280 pounds.

U.S. No. 3

U.S. No. 3 grade feeder pigs are slightly short, have a slightly small frame, and have glightly thin muacling. When this animal reaches ideal market weight of about 280 pounds it will have a high degree of fatnesg. From the rear the shoulders, loin, and hams are about the game width because of slight muscling and a relatively high degree of fatmess. The legs are set fairly.close together since the animal is slightly muscled. When viewed from the side, the animal already shows signs of fat deposition even at a young age in the jowl and flank. Feeder pigs in this grade are expected to produce U.S. No. 3 grade carcasses when slaughtered at $280 \mathrm{Ib}$

U.S. No. 4

U.S. No. 4 grade feeder pigs have thin muscling, are ghort, and have a small frame. At $280 \mathrm{lh}$, this animal will have a very high degree of fatness. These animals are uniform in width through the hams and loins, and the back is rather flat. Also, the legs are get close together because of the thin muscling. Even at this size, from the side he is beginning to look wastey due to excess fatness. The jowl and flank are moderately full. Also, the lower parts of the hams are beginning to fill with fat. Feeder pigs in this grade are expected to produce U.S. No. 4 grade carcasses when slaughtered at $280 \mathrm{Ib}$

U.S. Utility

U.S. Utility grade feeder pigs are gmall for their age and are often unthrifty because of disease or poor care. However, this unthrifty condition is not so serious that they could not recover without proper care and treatment. Indications can include wrinkled skin, a rough, unkempt appearance, and a head that appears larger than normal. If their unthrifty condition is corrected, pigs in this grade may become a No. 1, 2, 3, or 4 at $280 \mathrm{lb}$. U.S. Utility grade feeder pigs whose unthrifty condition is not corrected will produce U.S Utility grade carcasses.

Cull feeder pigs, although not shown, will be less thrifty and will require a long and costly feeding period to reach market weight if they are able to recover.

Figure 2. This USDA feeder pig grade chart can help visualize what to look for in a potential swine project (USDA, 1969). 


\section{Selecting a Feeder Pig for the Project Animal}

Choose a pig that has a slick hair coat, a tightly curled tail, plenty of energy, clear and bright eyes, and a healthy appetite. When selecting a market hog, one of the first questions to come up is, how big of a pig should I buy? This is an important question that can be answered by identifying a few key pieces of information:

1.What is your targeted end weight?

2.What is your targeted average daily gain?

3. How many days will your pig be on feed?

For example, if the pig will be on feed for 100 days, gaining 2 pounds per day, with an ideal finishing weight of 280 pounds: $280-200=80$, so the pig should weigh about 80 pounds at purchase.

More information about choosing a pig for the project is available in EDIS publication 4H-SWG-04, Selecting Pigs for Youth Swine Shows, http://edis.ifas.ufl.edu/4h210.

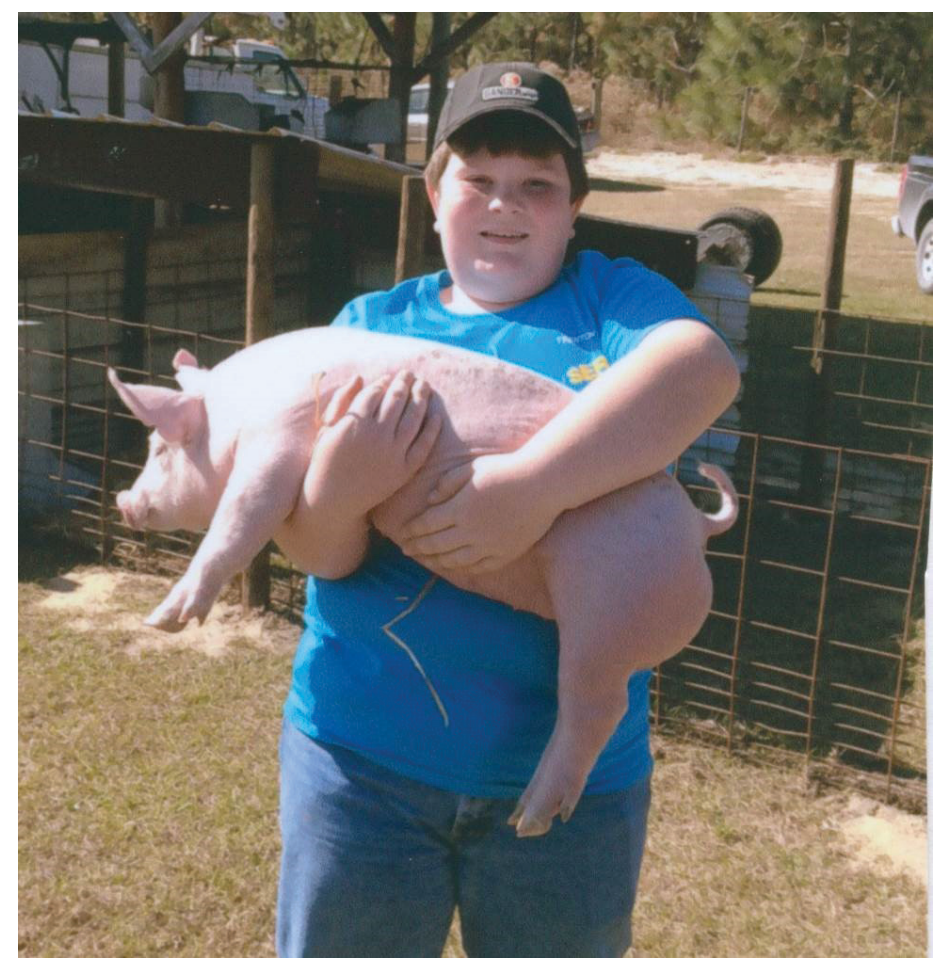

Figure 3. This 4-H member has chosen his pig for his market hog project.

\section{Building a Pen/Shelter}

It is a good idea to have your pig's pen ready before you bring the animal home. The first step in building a good pigpen is picking the right spot. You need to choose a location that is well-drained and that isn't too close to the house (sometimes pigpens can smell). You definitely don't want a spot that is too wet. Shade is also a consideration when picking where to place your hog, because hogs can sunburn quite easily.

Once you've chosen the best location, you need to decide what type of hog pen to build. How much money you want to spend influences this decision. You can set up a simple pen on soil or pour a concrete slab to build your pen on. Again, drainage is important for soil pens. Wood and cement floors are an option, but expense is an issue. These floors tend to keep hogs cleaner and more sanitary, but they still need to be cleaned out often and disinfected regularly. Pens built on well-drained, sandy soil should be at least 15 feet by 20 feet, and pens with a wood or cement floor need to be at least 10 feet by 20 feet. Pens on poorly drained soils are not ideal and need to be larger.

There are a variety of materials that you can use to fence in your pen. The cheapest is field fence, also called hog wire. Hog panels are also a popular choice because they are much sturdier than field fence. Some people use recycled materials like metal roofing or lumber to build a pen. Whatever you decide to use for the sides, remember that hogs are very strong. Use heavy posts, especially for corner posts. Also remember hogs love to root, so you need to bury your panels, fencing, or whatever siding you choose at least six inches. Many people find it helpful to run a strand of electric fence or other fencing deterrents a few inches off the ground inside the pen to discourage rooting under a fence. If field fence or any other type of woven wire is used, make sure the corner posts are wellbraced and the wire is stretched tight.

Most people find it easier to run a PVC water line or hose to an automatic water nipple that can secure to a post on the perimeter of the hog pen. This will ensure that the hog has a continuous supply of fresh, clean water. It's a good idea to have a shut-off valve above where the hog can reach in case the pig breaks a nipple or pipe, making 
it easier to repair. It is also okay to water a hog in a trough, but remember that you will have to clean it out every few days.

The animal will likely need some kind of shelter or cover to protect it from rain, cold, and the sun. It doesn't have to be anything fancy, just sturdy and cozy for your hog.

Keep in mind when building a pig pen that you're designing a pen not only to keep your hog confined, but also to keep potential predators like dogs and coyotes from getting to your show pig. Many dogs like pork!

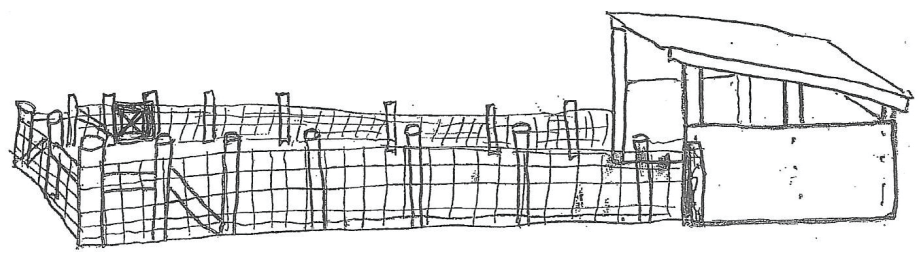

Figure 4. This drawing illustrates what a pig pen and shelter might look like for a market hog project.

\section{Materials/Supplies Needed to Raise a Show Hog}

Raising a show hog is a little more involved than raising a hog for your freezer. You need to train your hog to be used to handling and walking with a show stick, whip, or cane. You also need to provide for the animal's nutritional and medical needs. Here is a list of some items you will need, besides an adequate pen, to successfully complete a hog project:

- Brush

- Small Brush (to fit in back pocket at show)

- Nondetergent Soap

- Cane/Crop

- Trough/Feeder

- Water Trough/Nipple

- Bedding

- Show Box

- Closed-Toe Shoes

- Water Hose

- Grooming Supplies

- Spray Bottle

- Garbage Can/Feed Storage
- Shovel

- Rake

- Manure Fork/Pitchfork

- Rubber Boots

- Buckets

- Wheel Barrow

- Record Book

- Pens/Pencils

- Camera

- Veterinarian

- Livestock Trailer/Some means to transport a large hog to the fair

This list is not comprehensive. You might find other items helpful to make your hog project easier. Many items can be used for several years, and some can be shared by siblings/neighbors.

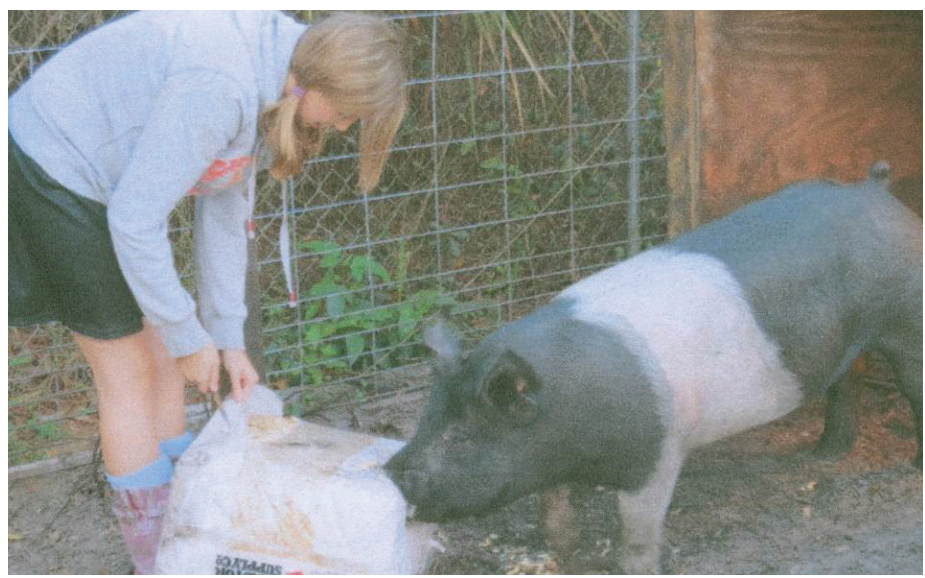

Figure 5. This 4-H member is adding shavings to her hog's shelter in preparation for cooler weather.

\section{Hog Health Needs}

In the world of agriculture, only healthy animals have the potential to make farmers money. Animals that are diseased or infested with parasites won't grow very well even if they eat the best feed. It is in one's best interest to take preventative steps to keep animals healthy. If an animal does become sick, you need to know how to recognize illness and know what to do in order to help your animal get better. Also remember to develop a good relationship with a large-animal veterinarian. He or she can make recommendations throughout your project as well as supply the health certificate you will need to 
show your hog. Try to learn as much as you can from your veterinarian. Understanding how to control internal and external parasites will also help you keep your project animal healthy.

\section{Internal Parasites}

The largest health concern for your hog will probably be internal parasites. Roundworms (nematodes) are the major worms in hogs. The most common of all is the large roundworm, or ascarid. Other worms can inflict more damage, like nodular worms, whip worms, thread worms, kidney worms, stomach worms, and lung worms. Usually cestodes, like tapeworms, aren't a problem in hogs. Protozoal diseases, usually coccidiosis, can also be a problem in pigs. A healthy pig in a clean pen shouldn't develop coccidiosis (Myer \& Brendemuhl, 2015).

You should strive to keep your pig pen as clean as possible. This will help protect your hog from parasites and disease. Once again, pigs on concrete are easier to prevent from getting worms than hogs kept on dirt. However, hogs raised on concrete can still get worms.

Most hog farmers should have already dewormed your pig before you buy it. Ask the farmer if and when he or she dewormed the pigs, and what product was used. If it has been over a month since the deworming, see if the farmer will deworm your pig again before you buy it. If not, do it as soon as you can after purchasing your animal. A good rule of thumb is to deworm the pig once every 30 days during the project. If the animal is exhibited in additional shows (and comingled with other pigs), additional deworming might be beneficial. Remember, worms rob your pig of weight gain and thriftiness, and you are spending money on expensive feeds to feed your animal, not internal parasites. Figure 6 illustrates in which specific organs internal parasites might exist in a pig.

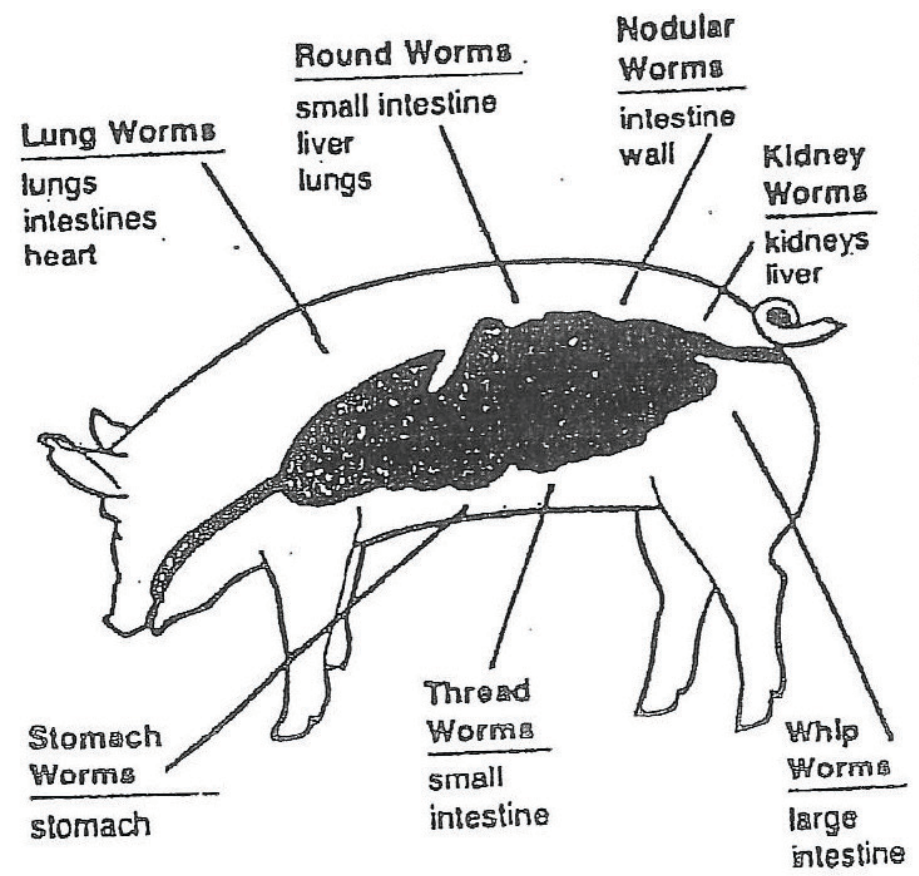

Figure 6. Locations where internal parasites might exist in a hog.

\section{External Parasites}

External parasites aren't as big a problem as internal parasites, but they can make your hog extremely uncomfortable and affect weight gains. The hog louse is a common external parasite in swine. In extreme infestations you will notice damage in the form of sores or lesions on the hog's ears and neck. Infested hogs will also scratch and rub a lot. Some hogs will spend time rubbing and scratching that they should spend eating. This constant rubbing causes the skin to get rough and the coat to grow coarse. This makes the hog look bad for the show. Bathing your hog and keeping its pen clean will help control lice. Insecticides are available in extreme cases; check with your veterinarian or local UF/IFAS Extension agent for advice (Kaufman, Koehler, \& Butler, 2019).

Mange is another external problem in hogs. Mange is a skin infection caused by mites. Hogs that are housed in the same pen or near each other can pass the mange mites to one another, so if you have a mangy hog, be careful that it doesn't infect all of your hogs. Insecticides are available to treat mange mites, and baths and a clean pen can help prevent mange mite infestations (Kaufman, Koehler, \& Butler, 2019). 
Swine diseases include pneumonia, pseudorabies (mad itch), and swine dysentery. If you buy from a reputable breeder, deworm regularly, and keep a clean pen, you should be well on your way to keeping a healthy hog. If you suspect a problem, call your veterinarian.

\section{Hog Nutritional Needs}

The major nutrients in a hog diet are water, carbohydrates, proteins (amino acids), fats, vitamins, and minerals. Hogs need feed and clean, fresh water every day. Most 4-Hers will buy a mixed, nutritionally balanced hog feed from a feed store to meet the remainder of the animal's nutritional needs. If you want to mix your own feed, contact your local UF/IFAS Extension office for more information. It is much easier to choose feed that is already nutritionally balanced, especially when feeding one or a few hogs. There are a variety of prepared feeds, from pig starters, growers, and finishers to rather expensive show diets. Check the ingredients on the feed tags and make sure growing diets have at least $15 \%$ protein and an adequate amount of the amino acid lysine. Most pigs purchased for 4-H projects will already be big enough to be moved to a hog-grower diet. Use a hoggrower feed until the hog reaches about 125 pounds, and then gradually change over to a finishing diet. The hog finisher has a little less protein, and carbohydrates might be a little less dense. This should keep your hog from over-finishing (getting too fat). There are some rather expensive show feeds available that claim they produce increased lean muscle growth. Remember, your feed will help your hog reach his genetic potential for growth. There is no feed available that will let your hog grow beyond its genetic potential for growth and muscling. Compare feed tags and try to find the feed that provides all the nutrients a growing hog needs for the lowest price. Make sure your hog has access to feed at all times (all the feed he can eat), and always make sure he has all the fresh, clean water he can drink available at all times.

\section{Training Your Hog for Showl Showmanship}

Daily exercise is important for your pig. At least a month before the fair (and ideally even earlier), you should start training your hog for the show. It is much easier for the judge to evaluate all the hogs in the show when they are walking around at their normal speed. At the show, your animal will be placed in a class with other pigs, usually grouped by similar weights. There will be several other hogs and exhibitors in the show ring with you and your hog. You need to be able to control your hog with a cane or whip during the show. Your showmanship skills will also be judged during the show, so control of the hog and how you present your animal to the judge are important.

Use a cane, stick, riding crop, or whip to control your hog's movements. You can get your pig to walk by gently tapping him on the side or belly. Never tap his ham or loin, and only tap him gently. Tap him gently on the left side of his face below the ear to turn him right. To turn him left, do the same thing on the right side of his face. To stop your hog, place the cane in front of his face.

Don't start training your pig to show too early, however, because it might get too used to the cane and ignore it. This might make him appear sluggish and lazy at the show. Don't practice in his pen; take him out in a fenced lot. If you have family members or neighbors with pigs, you might practice together to simulate a show.

Carry a small brush in your back pocket while you practice; you can do this in the show as well. If your pig gets dirt or other materials on him, you can quickly brush it off. Never brush your pig while the judge is looking, however. Don't spend a lot of time brushing your pig during the show.

\section{Record Book Tips}

The record book is one of the most important parts of a 4-H project. Learning to keep and organize accurate, meaningful records will be an asset throughout life. Many adults who went through the 4-H program still keep their old record books from 4-H projects they did as a child to have a memento from their past. 
Start your record book early. Do not wait until the week or day before the fair to try to cram a half a year into a record book. Try to update your record book at least weekly. Keep your record book clean and neat. Not only will this help you in record book judging, but you will have something to proudly display your $4-\mathrm{H}$ accomplishments when you are an adult.

Your project story and project pictures are just as important as accurate financial, health, and feed records. Make sure to use your best handwriting and remember this is your 4-H record book. Your parents can help, but you should be the one who actually does the record book.

\section{Conclusion}

Young people have a lot of choices when deciding what fun activities to get involved with. The 4-H market hog project is a very rewarding choice for youth because they learn many valuable life skills from raising and preparing a hog for a show.

Youth raising their first hog will have a lot of questions and a lot of tips to learn to raise a quality animal. Don't be afraid to ask your 4-H leaders, Extension agents, and veterinarians a lot of questions. These people care about you and want you to succeed. If you have raised a hog before, try to learn as much as you can about your hog project every year. There is always more to learn-always try to make the best better!

\section{References}

Kaufman, P. E., Koehler, P. G., \& Butler, J. F. (2019).

External Parasites on Swine. ENY-287. Gainesville:

University of Florida Institute of Food and Agricultural

Sciences. https://edis.ifas.ufl.edu/ig138

Myer, R. O., \& Brendemuhl, J. H. (2015). Controlling

Internal Parasites in Swine. AS50. Gainesville: University

of Florida Institute of Food and Agricultural Sciences.
Myers, N., Marshall, T. T., Walker, W. R., Prichard, D. L., Heltemes, B., DeCubellis, C. D., Estevez, B., TenBroeck, S. H., \& Carr, C. (2012). Selecting Pigs for Youth Swine Shows. 4H-SWG-04. Gainesville: University of Florida Institute of Food and Agricultural Sciences. http://edis. ifas.ufl.edu/4h210

Typical market pig today. (2019). Retrieved from https://www.pork.org/facts/stats/consumption-andexpenditures/typical-market-pig-today/

United States Department of Agriculture. (1969). United States Standards for Grades of Feeder Pigs. Washington, DC:Author. 